\title{
The application efficiency of organic fungicides against soybean diseases in the central zone of the Krasnodar region of the Russian Federation
}

\author{
Alexander Bushnev ${ }^{1}$, Sergey Babenko ${ }^{2}$, and Nadezhda Bushneva ${ }^{1},{ }^{*}$ \\ ${ }^{1}$ V.S. Pustovoit All-Russian Research Institute of Oil Crops, Filatova street, 17, Krasnodar, 350038, \\ Russia \\ ${ }^{2} \mathrm{OOO}$ "Biotechagro", Promyshlennaya street, 6 Zh, 352700 Timashevsk, Russia
}

\begin{abstract}
Diseases are one of the main factors limiting the receiving of high yields of soybean. The use of biopreparations for plant protection will result in successful disease control and improve the quality of products. In 2018-2020, at V.S. Pustovoit All-Russian Research Institute of Oil Crops (Krasnodar), we studied the application effectiveness of biopreparations under the trademarks of BSka-3 with the active ingredients Trichoderma veride, Pseudomonas koreensis, Bacillus subtilis and BFTIM with the active ingredient Bacillus amyloliquefaciens against soybean diseases. We applied organic fungicides for seed treatment and on vegetative plants at the budding stage. The variants BSka-3 G + BFTIM G (62\%) and BSka-3 $\mathrm{Zh}+$ BFTIM Zh (50\%) showed the highest biological effectiveness against purple Cercospora blight, and the variant BSka-3 E + BFTIM E showed $66 \%$ and $52 \%$ of effectiveness against pustular and angular spot diseases. The biological effectiveness of Pyraclostrobin, EC against purple Cercospora blight, pustular and angular spot diseases was the lowest -21 , 12 , and $10 \%$, respectively. We observed the best economic efficiency in case of application of BSka-3 E + BFTIM G $-2.31 \mathrm{t} / \mathrm{ha}$.
\end{abstract}

\section{Introduction}

Soybean (Glycine max (L.) Merr.) occupies a leading place among oil crops in the world production. It is cultivated for protein and oil, and has a fodder, nutritional and technical importance. For example, the use of soybean meal or cake in fodder production can increase the productivity of livestock and poultry and reduce feed consumption by $30-50 \%$. As a nitrogen-fixing crop, soybean improve the soil structure, enrich it with nitrogen and, therefore, it is one of the best predecessors for cereal crops. It can be grown in short (2-3 field) crop rotations with cereals [1-3].

The increase of soybean productivity is connected with the development of new varieties, improvement of general yield management and the introduction of technologies by producers. However, there are factors limiting the crop productivity [4]. One of them is diseases caused by fungi, bacteria, and viruses. Microorganisms infect soybean plants

\footnotetext{
*Corresponding author: naducha74@mail.ru
} 
during the entire growth season, causing a disorder in normal growth and development, and sometimes even the death of plants, premature aging, reduction of yield and seed quality, which lead to large financial losses $[3,5,6]$. The economic value of each disease varies from year to year depending on the environmental conditions. The differences in climate, distribution of pathogens and crop cultivation practices affect the prevalence of disease in each region $[7,8]$.

The effective chemical pesticides are used for protection of soybean sowings against diseases but strongly pollute the environment [9]. Therefore, the biological control of pathogens by means of microbial antagonists is becoming increasingly common in the system of crop protection due to their efficiency, availability, and a wide range of activity against phytopathogens $[10,11]$.

Out of the range of biological plant protection products based on microorganismsantagonists of pathogens, the preparations of multifunctional purposes with a wide range of antifungal activity are of particular value, which include biological preparations with the active ingredient of micromycetes of a genus Trichoderma spp. [12]. Powdered and liquid compositions of microorganisms contribute to a plant growth, a significant decrease in disease rate, an increase in seed germination, plant height and productivity indicators, and an increase in yield and additional income [11].

Soybean is one of the most popular crops in the agriculture of the Krasnodar region of the Russian Federation. The recent trend towards an increase in the soybean crop acreage leads to the accumulation of pathogenic infection and even greater prevalence of various diseases, which underlines the importance of development of a system for protecting crops against diseases. The tendency of goods producers to reduce the amount of pesticides used during crops cultivation stimulates the search for effective preparations against diseases based on microbiological antagonists.

In this regard, the aim of our research was to evaluate the biological and economic efficiency of organic fungicides in the system of protection of soybean sowings against diseases in the Krasnodar region.

\section{Materials and methods}

The results of fungicides tests based on microbiological antagonists against soybean diseases (variety Slavia) conducted in 2018-2020 in the central soil and climatic zone of the Krasnodar region at V.S. Pustovoit All-Russian research Institute of Oil Crops (Krasnodar) became the material for the article.

The growth and development of soybean during the growth season (from May to September) took place against under increased average daily temperatures (exceeding by 2.9-5.2 ${ }^{\circ} \mathrm{C}$ ), critically low precipitation in $2018-134.00 \mathrm{~mm}$, or $53.8 \%$ of the average long-term norm $(249 \mathrm{~mm})$, increased precipitation in $2019-321.5 \mathrm{~mm}$, or $129.0 \%$ of norm, and insufficient precipitation in $2020-226.4 \mathrm{~mm}$, or $90.9 \%$ of norm. However, the precipitation level of July $2020(99.8 \mathrm{~mm})$ during the period of bean filling was favorable for development of a high yield in soybean plants. Therefore, 2018 was characterized as unfavorable for the crop, and 2019 and 2020 as moderately favorable.

We tested four variants of soybean protection systems against diseases. Each system consisted of: treatment of soybean seeds with biofungicides of the company OOO "Biotechagro" under the BSka-3 trademark based on Trichoderma veride, Pseudomonas koreensis, Bacillus subtilis (various strains of antagonists) and treatment of plants at the budding stage with biofungicides of the company OOO "Biotechagro" under the BFTIM trademark based on Bacillus amyloliquefaciens (titer $1 \times 10^{9} \mathrm{CFU} / \mathrm{ml}$ ) (various strains of antagonist). We chose the variant with untreated soybean seeds and plants as a control, and 
the variant with soybean seeds and plants treated with the recommended chemical fungicides (Table 1) as a standard.

Table 1. The scheme of a field test of protection systems of soybean sowings against diseases in the Krasnodar region, 2018-2020

\begin{tabular}{|l|l|l|c|}
\hline \multirow{2}{*}{ № } & \multicolumn{1}{|c|}{ System } & $\begin{array}{c}\text { Application method of } \\
\text { preparation }\end{array}$ & $\begin{array}{c}\text { Application } \\
\text { rate }\end{array}$ \\
\hline \multirow{2}{*}{1} & \multirow{2}{*}{ Control } & without treatment & - \\
\cline { 2 - 4 } & without plant treatment & - \\
\hline \multirow{2}{*}{2} & Fludioxonil, SC $(25 \mathrm{~g} / \mathrm{l})-$ standard & seed treatment & $21 / \mathrm{t}$ \\
\cline { 2 - 4 } & Pyraclostrobin, EC $(200 \mathrm{~g} / \mathrm{l})-$ standard & plant treatment & $0.51 / \mathrm{ha}$ \\
\hline \multirow{2}{*}{3} & BSka-3 A, LC & seed treatment & $71 / \mathrm{t}$ \\
\cline { 2 - 4 } & BFTIM A, LC & plant treatment & $21 / \mathrm{ha}$ \\
\hline \multirow{2}{*}{4} & BSka-3 G, LC & seed treatment & $81 / \mathrm{t}$ \\
\cline { 2 - 4 } & BFTIM G, LC & plant treatment & $21 / \mathrm{ha}$ \\
\hline \multirow{2}{*}{5} & BSka-3 E, LC & seed treatment & $81 / \mathrm{t}$ \\
\cline { 2 - 4 } & BFTIM E, LC & plant treatment & $21 / \mathrm{ha}$ \\
\hline \multirow{2}{*}{6} & BSka-3 Zh, LC & seed treatment & $81 / \mathrm{t}$ \\
\cline { 2 - 4 } & BFTIM Zh, LC & plant treatment & $21 / \mathrm{ha}$ \\
\hline
\end{tabular}

We tested the soybean seeds for germination and seed infection in laboratory conditions in accordance with the State Standard [GOST 12038-84, 2011] before conducting the field experiment. We carried out the presowing treatment of soybean seeds with fungicides on a laboratory incrustator "Hege". The sowing was carried out with a "GASPARDO-MT 8" seeder according to the scheme with a seeding rate of 450.000 seeds/ha, the number of experiment replications was three, and the size of one plot was $112 \mathrm{~m}^{2}$. We recorded all manifestations of diseases and made calculation of the biological effectiveness of fungicides according to the guidelines for registration testing of fungicides in agriculture [13]. Soybean was harvested using an Acros-530 combine; the yield was normalized to 100 $\%$ of purity and $14 \%$ of moisture content. We processed the research data by analysis of variance using the SPSS software.

\section{Results and discussion}

We determined the sowing qualities of soybean seeds and their infestation with pathogens before sowing. We found that the laboratory germination of seeds untreated with fungicides was lowered - at the level of $79 \%$ due to the presence of a seed infection complex, consisting of the fungi Alternaria spp., Fusarium spp., Mucor spp. and bacteria (Xanthomonas spp., Pseudomonas spp.) with the number of affected seeds and seedlings 28, 12, 15 , and $40 \%$, respectively. The seed treatment with fungicides had a positive effect on their germination by reducing the infection with pathogens. For example, in variants with seed treatment with BSka-3, germination exceeded the control and reached 83-88 \%, and it was the highest, $94 \%$, when the seeds were treated with Fludioxonil, SC. The infection of seeds and seedling with the fungi of Alternaria spp. decreased by $36-78 \%$ in variants in comparison with the control, with Fusarium spp. - by 84-100\%, and with Mucor spp. - 80-92\%. The fungicides BSka-3 A and BSka-3 E controlled the infection best of all, the infection of seeds and seedling with bacteria in these variants decreased by 62 and $65 \%$, the effectiveness of Fludioxonil, SC was the lowest $-51 \%$. The overall decrease in the number of affected seeds and seedlings by variants of experiment varied from 64 to $81 \%$ (Table 2). 
Table 2. The effect of fungicide treatment on laboratory germination and seed infection of seeds and seedlings of soybean, variety Slavia, V.S. Pustovoit All-Russian Research Institute of Oil Crops, 2018-2020

\begin{tabular}{|c|c|c|c|c|c|c|c|}
\hline \multirow[b]{2}{*}{ Variant } & \multirow[b]{2}{*}{$\begin{array}{c}\text { Application } \\
\text { rate, } \\
1 / \mathrm{t}\end{array}$} & \multirow{2}{*}{ 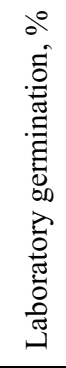 } & \multicolumn{5}{|c|}{$\begin{array}{l}\text { Infection decrease of seeds and } \\
\text { seedlings, } \%\end{array}$} \\
\hline & & & 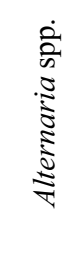 & 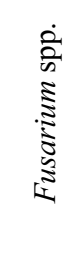 & 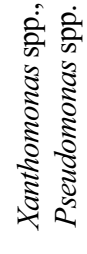 & 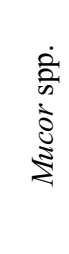 & $\stackrel{\varpi \pi}{0}$ \\
\hline Control (without treatment) & - & 79 & $28^{*}$ & $12 *$ & $40^{*}$ & $15^{*}$ & $48^{*}$ \\
\hline Fludioxonil, SC - standard & 2.0 & 94 & 78 & 100 & 51 & 85 & 81 \\
\hline BSka-3 A, LC & 7.0 & 86 & 71 & 92 & 62 & 87 & 70 \\
\hline BSka-3 G, LC & 8.0 & 84 & 54 & 100 & 60 & 80 & 67 \\
\hline BSka-3 E, LC & 8.0 & 88 & 56 & 84 & 65 & 92 & 72 \\
\hline BSka-3 Zh, LC & 8.0 & 83 & 36 & 90 & 55 & 85 & 64 \\
\hline
\end{tabular}

* - affected seeds and seedlings in the control, \%

We carried out the sowing in the last 10 days of April; the seedlings were fully appeared at the end of the first 10 days of May. During all years of research, soybean seedlings emerged 2-3 days earlier in the variants with the application of BSka-3 fungicides than in standard and control.

In the conditions of 2018-2020, the vegetative soybean plants were affected by Colletotrichum truncatum (Schw.) Andrus et Moore, Macrophomina phaseolina (Tassi) Goid, Peronospora manschurica (Naum) Syd; however, their prevalence on the control did not exceed $10 \%$, and the disease development was at the level of 1-2 points.

The most prevalent diseases in the experiment were purple Cercospora blight (the causative agent is Cercospora kikuchii Gardner) and bacterioses: pustular spot disease (the causative agent is Xanthomonas glycines (Nakano) and angular spot disease (the causative agent is Pseudomonas savastanoi pv. glycinea (Coerper). The symptoms of diseases appeared on soybean plants after flowering at the stage of bean formation. The prevalence of purple Cercospora blight varied from 6 to $16 \%$, depending on the variant of the experiment, and was the highest in the control. The frequency of occurrence of pustular spot disease in the control and standard variants was at the same level $-24 \%$, and was the lowest, $12 \%$, in the BSka-3 G + BFTIM G system. The prevalence of angular spot diseases reached $30 \%$ in the control, in other variants it varied from $14 \%$ in the BSka-3 Zh + BFTIM $\mathrm{Zh}$ system to $26 \%$ in the standard. By the time of ripening, we observed an increase in the prevalence of these diseases for all variants of the experiment.

Based on the results of records of the diseases prevalence, we calculated the biological effectiveness of fungicides. The protection systems BSka-3 G + BFTIM G (62\%) and BSka-3 Zh + BFTIM Zh (50\%) showed the best biological effectiveness against purple Cercospora blight. The chemical standard reduced the disease prevalence by $21 \%$, and the use of the BSka-3 E + BFTIM E did not affect the disease prevalence. We noted the highest efficiency against pustular and angular spot diseases in case of application the BSka-3 E + BFTIM E system - 66 and $52 \%$, respectively, and the standard variant had the minimum effectiveness against bacterioses -12 and $10 \%$ (Table 3 ). 
Table 3. The effectiveness of protection systems against the diseases complex of soybean plants, variety Slavia, (Krasnodar), 2018-2020

\begin{tabular}{|l|c|c|c|c|c|}
\hline & & \multicolumn{3}{|c|}{ Biological effectiveness } & \multirow{2}{*}{ Variant } \\
\cline { 3 - 5 } & $\begin{array}{c}\text { Application } \\
\text { rate, } \\
\text { 1/ha }\end{array}$ & $\begin{array}{c}\text { purple } \\
\text { Cercosp } \\
\text { ora } \\
\text { blight }\end{array}$ & $\begin{array}{c}\text { pustular } \\
\text { spot } \\
\text { disease }\end{array}$ & $\begin{array}{c}\text { angular } \\
\text { spot } \\
\text { disease }\end{array}$ & $\begin{array}{c}\text { Producti } \\
\text { vity, t/ha }\end{array}$ \\
\hline Control (without treatment) & - & $40^{*}$ & $58^{*}$ & $62^{*}$ & 1.99 \\
\hline $\begin{array}{l}\text { Fludioxonil, SC + } \\
\text { Pyraclostrobin, EC - standard }\end{array}$ & $2.0+0.5$ & 21 & 12 & 10 & 2.09 \\
\hline BSka-3 A, LC + BFTIM A, LC & $7.0+2.0$ & 25 & 48 & 42 & 2.21 \\
\hline BSka-3 G, LC + BFTIM G, LC & $8.0+2.0$ & 62 & 42 & 38 & 2.24 \\
\hline BSka-3 E, LC + BFTIM E, LC & $8.0+2.0$ & 0 & 66 & 52 & 2.31 \\
\hline BSka-3 Zh, LC + BFTIM Zh, LC & $8.0+2.0$ & 50 & 28 & 34 & 2.27 \\
\hline HMD05 & & & & & 0.23 \\
\hline
\end{tabular}

*- the diseases prevalence in the control, \%

We determined the economic efficiency of the protection systems after soybean ripening. On average, the soybean productivity was at the level of $1.99-2 / 31$ t/ha by the variants of the experiment, the saved yield was $0.10-0.32 \mathrm{t} / \mathrm{ha}$. The application of the BSka$3 \mathrm{E}+$ BFTIM E protection system against diseases led to the highest yield in the experiment $-2.31 \mathrm{t} / \mathrm{ha}$.

\section{Conclusions}

The organic fungicides based on microbiological antagonists against soybean diseases under the BSka-3 trademark efficiently suppressed seed infection. Moreover, fungicides BSka-3 A and BSka-3 E better controlled bacterial infection, the infection of seeds and seedlings decreased by 62 and $65 \%$, respectively, in case of Alternaria spp. - BSka-3 A (78 \%), and in case of Fusarium spp. - BSka-3 G (100\%).

The treatment of soybean plants during the growth season with BFTIM G and BFTIM $\mathrm{Zh}$ reduced the prevalence of purple Cercospora blight by 62 and $50 \%$, respectively. BFTIM E was the most effective against pustular and angular spot diseases -66 and $52 \%$, respectively. The biological effectiveness of Pyraclostrobin, EC against purple Cercospora blight, pustular and angular spot diseases was the lowest $-21,12$, and $10 \%$, respectively. The best economic efficiency was achieved in case of using BSka-3 E for seed treatment and the treatment of soybean plants at the budding stage with BFTIM $\mathrm{G}-2.31 \mathrm{t} / \mathrm{ha}$.

\section{References}

1. A. Karlekar, A. Seal, Computers and Electronics in Agriculture, 172 (2020)

2. Y. Wu, F. Yang, W. Gong, S. Ahmed, Y. Fan, X. Wu, T. Yong, W. Liu, K. Hu, J. Liu, J. Du, W. Yang, Journal of Integrative Agriculture, 16, 1331 (2017)

3. V. M. Lukomets, V. T. Piven, A. V. Kochegura, N. A. Bushneva, A. I. Dryakhlov, Oil crops. Scientific and Technical bulletin of VNIIMK, 1 (136), 66 (2007)

4. A.A. Henning, A.M.R. Almeida, C.V. Godoy, C.D.S. Seixas, J.T. Yorinori, L.M. Costamilan, L.P. Ferreira, M.C. Meyer, R.M. Soares, W.P. Dias, Manual de identificação de doenças de soja (2014)

5. S. Reznikov, V. De Lisi, P. Claps, V. González, M.R. Devani, A.P. Castagnaro, L.D. Ploper, Crop Protection, 124 (2019) 
6. V.T. Piven, G.M. Saenko, I.I. Shulyak, Oil crops Scientific and Technical bulletin of VNIIMK, 1 (140), 120 (2009)

7. M. Santha, L. Prasad, M. Sujatha, K. Alivelu, K. Sujatha, Crop Protection 92, 70 (2017)

8. S.G. Markell, R. Harveson, C.C. Block, T. J. Gulya, Sunflower chemistry, production, processing, and utilization, 93 (2015)

9. W.-T. Chang, M.-L. Chen, S.-L. Wang, World Journal of Microbiology and Biotechnology, 26, 945 (2010)

10. M. Kgatle, B. Fletty, M. Truter, T. Aveling, Crop Protection 132, 105 (2020)

11. A. Abbas, S. Ullah, K. Wasim, U. Khanc, T.A. Saleh, M.H.U. Khan, S. Ullah, A. Ali, M. Ikram, Comptes Rendus Biologies, 342, 124 (2019)

12. R.N. Silva, V.N. Monteiro, A.S. Steindorff, E.V. Gomes, E.F. Noronha, C.J. Ulhoa, Fungal Biology, 123, 565 (2019)

13. K.V. Novozhilova, A.I. Anisimov, Guidelines for registration testing of fungicides in agriculture (2009) 